\title{
TEM Approach in Investigations of Microbially Assisted Uranium Reduction
}

\author{
Alice C. Dohnalkova, David W. Kennedy, and Jim K. Fredrickson
}

Environmental Microbiology, Pacific Northwest National Laboratory, MS P7-50, Richland, WA 99352

Dissimilatory metal reducing bacteria (DMRB) have been a focal point of numerous studies for their ability to yield energy for maintenance by coupling the oxidation of organic matter or hydrogen to the reduction of metal oxides during anaerobic respiration [1]. The capacity of DMRB to reduce polyvalent metals and radionuclides has received significant attention in light of potential application of these organisms in the bioremediation of contaminated soils. Soluble U(VI) is highly mobile in most groundwaters, while U(IV) precipitates readily as the insoluble mineral uraninite [2]. Accordingly, the controlled production of microbially reduced uraninite by stimulation of U(VI)reducing bacteria in contaminated subsurface environments may be a useful strategy for in situ uranium immobilization.

Bacterial reduction of U(VI) by Shewanella putrefaciens strain CN-32 was studied in the presence and absence of Mn (III/IV) oxides to determine the influence and potential competition of naturally co-existing electron acceptors during the redox cycling process. Poorly soluble synthetic Mn minerals pyrolusite $\left(\beta-\mathrm{MnO}_{2}\right)$, bixbyite $\left(\mathrm{Mn}_{2} \mathrm{O}_{3}\right)$ and $\mathrm{K}^{+}$-birnessite $\left(\mathrm{K}_{4} \mathrm{Mn}_{14} \mathrm{O}_{27} 8 \mathrm{H}_{2} \mathrm{O}\right)$, were used in batch experiments with uranyl acetate as a source of soluble U(VI) with $2-4 \times 10^{8}$ cells $/ \mathrm{mL}$ of $\mathrm{CN}-32$. The rate of $\mathrm{U}(\mathrm{VI})$ and $\mathrm{Mn}(\mathrm{IV})$ reduction in solution and the composition of precipitated solids was studied by a variety of analytical methods [3]. High resolution TEM was employed to determine the morphology and distribution of newly formed biominerals located within the cross-sectioned cell.

A novel approach in anaerobic sample preparation for TEM was developed in our lab to visualize sites of preferred mineral formation, enabling us to examine the cell-mineral interface in detail [4]. To preserve cell morphology and the exact composition of biominerals, we use strictly anoxic conditions for suspensions embedding and microtomy, excluding most fixatives and all heavy metal stains. TEM analysis of material thin sections revealed that the periplasm, an area with very high enzymatic activity located between the inner and outer membrane, was a primary site of newly formed minerals. Depending on the reaction system, secondary nodular deposits were formed on the cell surface (fig.1B). The elemental composition of these phases was determined by Energy Dispersive Spectroscopy (EDS) to be predominantly uranium with no detectable traces of Mn directly associated with the cells. High resolution imaging revealed uniform nanocrystalline structure with a typical particle size of $5 \mathrm{~nm}$ or less on the cell surface deposits. No distinctive d-lines were evident in the periplasm, suggesting either poor crystallinity or overlapping particles below $2 \mathrm{~nm}$. Selected Area Electron Diffraction (SAED) of extracellular and periplasmic precipitates yielded a ring pattern with d-spacings characteristic for uraninite.

The distribution of biogenic $\mathrm{UO}_{2}$ is consistent with the current understanding of electron transfer mechanisms in DMRB, where the metal reductase activity is associated with the cell membrane, periplasm and outer membrane. Due to low solubility of reduced U(IV), uraninite probably precipitated at or near the actual site of reduction. The high density of $\mathrm{UO}_{2(\mathrm{~s})}$ within the cell is quite remarkable and demonstrates the cells high tolerance to intracellularly precipitated minerals. The cell 
population did not show any signs of lysing, however, general cell viability was not determined. Our results indicate that $\mathrm{Mn}$ (III/IV) oxides slowed down the bioreduction of U(VI). In addition to competition of electron acceptors, newly formed biogenic $\mathrm{UO}_{2(\mathrm{~s})}$ can be reoxidized by $\mathrm{Mn}(\mathrm{III} / \mathrm{IV}$ ). However, the accumulation of U(IV) in the periplasm may physically protect reduced uraninite from reoxidation. These results demonstrate that the presence of Mn oxides in subsurface may impede the bioreduction of U(VI) in subsoils and sediments.

\section{References:}

[1] Lovley DR (1993) Dissimilatory metal reduction. Annu. Rev. Microbiol. 47, 263-290

[2] Lovley DR, J Indus Microbiol 14, 263-290

[3] Fredrickson JK. et all (2002), Geochim. Cosmochim. Acta, submitted

[4] Dohnalkova AC. et all (2001) Microsc. and Microanal. proc. Vol 7, suppl.2, 756-7

[5] This research was funded by DOE's Natural and Accelerated Bioremediation Research Program (NABIR). It was conducted in the Environmental Molecular Sciences Laboratory (EMSL), a national scientific user facility sponsored by the DOE's Office of Biological and Environmental Research, located at PNNL in Richland, WA.
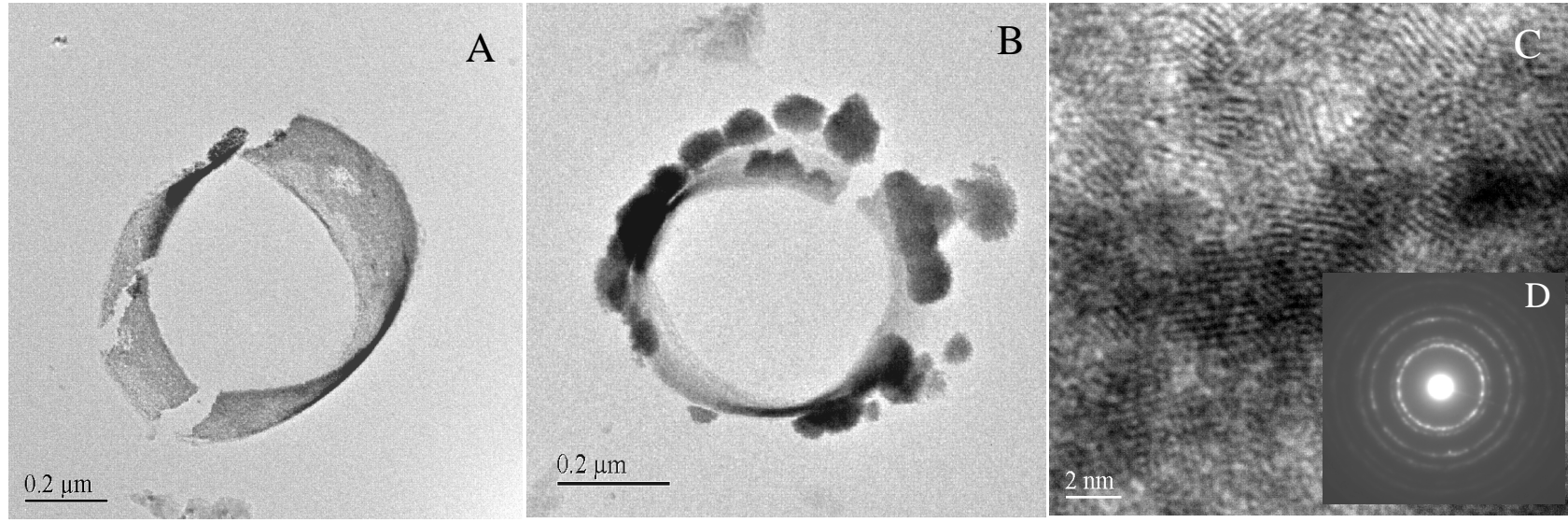

Fig.1. TEM images of unstained sections from: (A) S. putrifaciens $\mathrm{CN}-32$ incubated with $\mathrm{H}_{2}$ and U(VI) in bicarbonate buffer with birnessite shows biogenic uraninite deposited in the periplasm. The cylindrical shape of the precipitated mineral outlines the space with the most enzymatic activity. (B) Heavy extracellular accumulation of U(IV) on the cell surface of $\mathrm{CN}-32$ incubated in the absence of Mn oxides. The contrast of the cells is compromised since all stains were omitted during slurry processing to preserve the redox situation. (C) A high resolution image of extracellular solids with visible d-lines reveals nanocrystalline structure. Inset (D): SAED ring pattern of biogenic uraninite. 